\title{
DEFINING TERRORISM: ONE SIZE FITS ALL?
}

\author{
Alan GreEnE*
}

\begin{abstract}
This article challenges the idea, both in domestic and international law, of defining terrorism. Using section 1 of the UK's Terrorism Act 2000 as an illustrative example, this article argues that a single definition of terrorism is invariably broad owing to the need to accommodate the lowest common denominator. This is damaging to the 'principle of legality' as recognized in British public law and the ECHR. Moreover, this problem is further exacerbated by the increasing application of counterterrorism legislation to non-international armed conflicts. This article therefore suggests an alternative solution: multiple definitions of terrorism whose breadth is dependent upon the specific circumstances for which they are designed. Fears that such an approach may amount to an 'expression of inconsistency' will be addressed by arguing that law's capacity to shape and frame public and political debate on the concept of terrorism is over-exaggerated. Legal definitions of terrorism therefore should remain primarily concerned with the legal rather than political function of defining terrorism.
\end{abstract}

Keywords: human rights, international law, non-international armed conflicts, public law, rule of law, terrorism.

\section{INTRODUCTION}

'The UK uses the same legal definition for every situation in which "terrorism" is a legally-relevant category.' 1 This definition, in section 1 of the Terrorism Act 2000, is vague, broad and widely criticized by experts, courts and academics. Yet the decision to take a 'one-size fits all' approach to defining terrorism was taken without much consideration of alternatives and there has been little appetite for questioning this approach since. This article outlines the wideranging difficulties with both the current definition as it stands and the notion

* Lecturer in Law, Durham University Law School, alan.greene@durham.ac.uk. I would like to thank Colin Murray, Fiona de Londras, Ntina Tzouvala and the anonymous reviewers for their helpful comments and suggestions on this article.

1 With the one narrow exception of the Reinsurance (Acts of Terrorism) Act 1993 which is specifically for the purposes of defining terrorism for insurance claims. Section 2(2) of the Act defines terrorism as: 'acts of persons acting on behalf of, or in connection with, any organisation which carries out activities directed towards the overthrowing or influencing, by force or violence, of Her Majesty's government in the United Kingdom or any other government de jure or de facto'. 
of a single definition for terrorism that can be applied across multiple, highly varied, legal contexts. It is argued that it is preferable to adopt a multidefinitional approach to the concept of terrorism in legal terms, with the definition used being determined by the powers exercisable in respect of it. This would work as a sliding scale: the more intrusive, repressive and oppressive the powers the narrower the definition. Such an approach is entirely consistent with the idea that the greater the exercise of State power the clearer, tighter and more limited the definition that empowers the State should be. This is, as Lord Bingham has observed, key to limiting discretion and thus maintaining the rule of law and stands in sharp contrast to the status quo. $^{2}$

This article commences by questioning the need to legally define terrorism in the first instance, distinguishing between the descriptive definitions of the social sciences and the prescriptive exercise that the law undertakes. While a distinction will also be made between domestic and international requirements for a single legal definition, it will be argued that these two spheres are not wholly severable from each other, notwithstanding the fact that the geopolitical factors making the quest for an internationally agreed definition of terrorism almost impossible do not necessarily play out in national politics. A common theme recurring in these various disciplines regarding the definition of terrorism is the key role that the labeller plays in identifying who or what is a terrorist and the delegitimizing effect that this categorization has. An important issue related to this is the idea that by legally defining terrorism, the use of the term can be controlled.

Using the UK definition of terrorism as a case study, Part III argues that a single definitional approach to terrorism results in a 'race to the bottom', requiring the broadest possible definition in order to accommodate every possible scenario. This, in turn, confers extensive discretion on decision makers which is applied in an inconsistent and unclear manner, undermining the principle of legality as reflected in British constitutional law, and the European Convention on Human Rights (ECHR). This problem is further exaggerated by the increasing application of this definition of terrorism overseas in non-international armed conflicts and the issue of British citizens engaging in terrorist activities overseas returning to the UK. ${ }^{3}$

In light of this, Part IV advances an argument in favour of a multi-definitional approach to the concept of terrorism. Concerns that this approach would amount to an expression of inconsistency or would reduce law's ability to control the use of the term 'terrorism' are addressed in Part V. These concerns overstate the role that law plays in framing political debates, ignoring the powerful

2 See T Bingham, The Rule of Law (Penguin 2011) ch 4.

3 D Anderson, 'The Terrorism Acts in 2014: Report of the Independent Reviewer on the Operation of the Terrorism Act 2000 and Part I of the Terrorism Act 2006' (September 2015) at $<$ https://terrorismlegislationreviewer.independent.gov.uk/wp-content/uploads/2015/09/TerrorismActs-Report-2015-Print-version.pdf $>2$. 
political and social forces that instead shape public perceptions of what constitutes terrorism.

\section{DEFINING TERRORISM}

The quest for a satisfactory definition of terrorism, described by Nicholas $\mathrm{J}$ Perry as the search for the 'Holy Grail', is one pursued by law and various other branches of the social sciences. ${ }^{4}$ To define terrorism, however, assumes that such a phenomenon exists. As a concept, terrorism has oscillated in meaning, reflecting ideas contextually specific to the time period and location to which it is being applied. Many etymological studies of the origins of terrorism trace the term back to the aftermath of the French Revolution and Maximilien Robespierre's 'reign of terror' between 1792 and 1794. ${ }^{5}$ The Oxford English Dictionary first mentions the word 'terrorism' in 1795, shortly after this violent period, and today the Oxford English Dictionary still starts its definition of terrorism with this 'at once too literal and too historical' definition. ${ }^{6}$ As a result, this definition is, according to Bruce Hoffmann, not 'of much use' when trying to understand the concept of terrorism. ${ }^{7}$ Terrorism has deviated from this original meaning of State-sponsored violence designed to induce fear and terror in order to control and dominate an otherwise anarchical society, to describe the exact opposite: political violence directed against the State. In the late nineteenth and early twentieth centuries, terrorism was often used to refer to anarchists, particularly following the assassination of US President William McKinley in 1901 by Leon Czolgosz-a self-confessed anarchist. ${ }^{8}$ At the same time, in Europe terrorism was gaining its connection with 'freedom fighters' as a result of renewed struggles for Irish independence from Britain using tactics such as bombings, assassination techniques and guerrilla warfare. ${ }^{9}$ This evolution from Statesponsored to State-targeted terrorism was not linear, however; in the 1930s, terrorism again became associated with State-sponsored violence due to the rise of violent, authoritarian regimes in Italy, Spain and Nazi Germany. ${ }^{10}$ Following the end of World War II and the decline of the European empires, terrorism again became linked with freedom fighters and the violent methods used by various anti-colonialist groups seeking self-determination. ${ }^{11}$ Today, these two issues of whether States can commit terrorism, and whether one can distinguish the terrorist from the freedom fighter struggling against an oppressive regime are the fundamental problems afflicting attempts to provide a definition of terrorism in international law. ${ }^{12}$

4 NJ Perry, 'The Numerous Federal Legal Definitions of Terrorism: The Problem of Too Many Grails’ (2004) 30(2) Journal of Legislation 249.

5 B Hoffmann, Inside Terrorism: Revised and Expanded Edition (Columbia University Press 2006) 2. $\quad{ }^{6}$ C Gearty, The Future of Terrorism (Phoenix 1997) $5 .{ }^{7}$ Hoffmann (n 5).
8 ibid 7.
9 ibid 8-9.
10 ibid 14.
11 ibid 16.
12 See (n 23). 


\section{A. Terrorism: A Social Construct}

Terrorism therefore is a social construct, its meaning shaped by the subjective perspectives of the categorizer. ${ }^{13}$ These in turn are influenced by the society and circumstances in which the categorizer finds themselves in, varying upon the historical and political context in which they live. Consequently, attempts to understand terrorism have spawned a vast array of different methodologies, paradigms and branches of knowledge. Certain branches of 'terrorism studies' may be conceptualized as cultural anthropology, viewing 'terrorists' as natives that need to be studied. ${ }^{14}$ Under this approach, the subject of study is the terrorist actor. Contrasting approaches to understanding terrorism instead train their lens upon those labelling terrorists as such. These 'critical terrorism studies' emphasize the subjective nature of terrorism and seek to unveil the power dynamics at play in constructing these labels. ${ }^{15}$ Discourse-centred terrorism studies instead look not necessarily at the categorizer or the categorized, but at the discourse surrounding terrorism to reveal the nature of terrorism. ${ }^{16}$ This constructivist approach conceptualizes terrorism as possessing certain objective criteria; however, it also acknowledges that there are powerful subjective forces at play in constructing this object. ${ }^{17}$

The need for a definition of terrorism also varies according to the different fields undertaking the quest. Sociologists and criminologists require one in order to define the parameters of that which they study. ${ }^{18}$ Theirs is, for the most part, a descriptive endeavour. Despite this need, however, a famous 1988 survey found over 100 definitions used by terrorism researchers in the literature. ${ }^{19}$ This has been described as 'a perverse situation where a great number of scholars are studying a phenomenon, the essence of which they have ... agreed to disagree upon'. ${ }^{20}$ Law, however, is not merely a descriptive exercise but is predominately a prescriptive (and indeed a proscriptive) exercise. The normative factors that accompany this prescriptive exercise are ones which the sociologist may not necessarily have to confront. ${ }^{21}$ Relatedly, terrorist studies that scrutinize the power structures at play in the labelling of an event or individual as 'terrorist', reveal that terrorism is a pejorative term, loaded with condemnation that delegitimizes the political

13 R Jackson, L Jarvis, J Gunning and M Breen Smyth, Terrorism - a critical introduction (Palgrave MacMillan 2011) 164; D. Anderson, 'Shielding the Compass' (2013) 3 EHRLR 233, 240.

14 R Hülsse and A Spencer, 'The Metaphor of Terror: Terrorism Studies and the Constructivist Turn' (2008) 39(6) Security Dialogue 571, 573. $\quad 15$ ibid 575. 16 ibid 575-8.

17 ibid.

18 See AP Schmid and AJ Jongman, Political Terrorism: A New Guide to Actors, Authors, Concepts, Data Bases, Theories and Literature (Transaction Books 1988) ch 1.

20 D Brannan, P Esler and T Strindberg, "Talking to "terrorists" towards an independent analytical framework for the study of violent substate activism' (2001) 24 Studies in Conflict and Terrorism 3, 11; L Stampnitzky, Disciplining Terror: How Experts Invented "Terrorism" (Cambridge University Press 2013) 5.

21 J Blackbourn, F Davis and NC Taylor, 'Academic Consensus and Legislative Definitions of Terrorism: Applying Schmid and Jongman’ (2013) 34(3) Statute Law Review 239, 255. 
motive that the deed seeks to propagate. ${ }^{22}$ This 'labelling' is of paramount importance when understanding terrorism as a legal construct.

\section{B. Terrorism as a Legal Construct}

Much has been written on the difficulties surrounding a legal definition of terrorism; however, considerably less attention has been devoted to why there is a need to define terrorism in law in the first instance. The literature that does exist on this question tends to focus on debates in international law. Jörg Friedrichs' account of attempts to define terrorism in international law illustrates two major hurdles that have, to date, stumped this quest. ${ }^{23}$ Firstly, States fundamentally disagree as to the distinction between freedom fighters and terrorists. ${ }^{24}$ Secondly, States disagree as to whether a definition of terrorism in international law should cover State acts or not. ${ }^{25}$ These differences are politically and ideologically driven, with a State's perspective on the issue predicated by its own self-interests. Thus the UK in the past insisted on no distinction being made between terrorists and freedom fighters due to its struggles with the Irish Republication Army (IRA). ${ }^{26}$ Arab States took the opposite stance in defence of Palestinian resistance to Israeli occupation. ${ }^{27}$ A number of Arab States may, however, have changed their stance in the aftermath of the 'Arab Spring' and attempts - both successful and unsuccessful - to usher in internal regime change by various opposition groups.

International law has instead developed in a piecemeal manner, with treaties based upon specific crimes considered to be indicative of terrorism - eg plane hijacking and hostage taking. ${ }^{28}$ While lacking definitions of terrorism, this approach would be similar to a multi-definitional approach or 'inductive' approach to terrorism whereby the definition used is particular to the power or problem identified. ${ }^{29}$ The inductive approach does not commence with a broad hypothesis, but instead constructs its hypothesis based on observations. This hypothesis is then assessed against reality for accuracy. An inductive approach to defining terrorism thus does not necessarily seek to provide a universal definition covering all instances but instead defines terrorism to

22 Hoffmann (n 5) 23; AP Schmidt, 'The Definition of Terrorism' in AP Schmid (ed), The Routledge Handbook of Terrorism Research (Routledge 2011) 39-40.

23 J Friedrichs, 'Defining the International Public Enemy: The Political Struggle Behind the Legal Debate on International Terrorism' (2006) 19 LJIL 69, 76.

25 ibid 76-7.

24 ibid 72-6.

27 ibid 72-3. See also R Brulin, 'Defining “Terrorism”: The 1972 General Assembly debates on "international terrorism" and their coverage by the New York Times' in B Baybars-Hawks and L Baruh (eds), If It Was Not for Terrorism: Crisis, Compromise, and Elite Discourse in the Age of War on Terror (Cambridge Scholars Publishing 2011) 12.

${ }^{28}$ G Levitt, 'Is "Terrorism" Worth Defining?' (1986) 13(1) OhioNULRev 97,101; The European Union has also has a single definition of terrorism although the UK has adopted out of this. See Council Framework Decision 2002/475 on Combating Terrorism.

29 ibid 97. 
only cover specific situations that it can accommodate. ${ }^{30}$ An inductive approach therefore can consist of multiple separate definitions applicable to distinct situations. ${ }^{31}$ While an inductive approach resulting in multiple definitions of terrorism may be of little use to the social scientist who is seeking to define the parameters of that which they are studying, it may nevertheless be the case that it still has a function in the prescriptive and proscriptive function of the law.

In contrast to the inductive approach, the deductive approach starts out with a general definition of terrorism and applies this to numerous different circumstances. ${ }^{32}$ For deductive reasoning to operate effectively, the initial hypothesis must be correct, and, indeed it must be agreed upon in the first instance and it is this hurdle that international law has not yet managed to cross. A deductive approach would be expected to produce a single definition of terrorism.

A number of different arguments have been put forward as to why a single definition of terrorism is preferable to a multi-definitional approach. Christian Walter, for example, argues that clarity and certainty are key justifications for a single legal definition of terrorism:

The main reason for slightly different definitions is not a decision on the purpose by the legislator, but rather the adoption of different measures at different times and a corresponding lack of co-ordination. For the purpose of clarity and legal certainty it would be desirable to adopt as much as possible a single definition of 'terrorism' within any given legal order. ${ }^{33}$

A similar argument in the international context is put forward by Ben Golder and George Williams who argue that as 'terrorism' has entered the political discourse, the law is to keep pace with this discussion by reflecting our current understanding of terrorism and "crystallising it in a form consistent with rule of law principles'. ${ }^{34}$

Also referring to the international debate, Alex Schmid argues that a single definition would avoid the 'defeatist' position that one man's terrorist is another man's freedom fighter, thus moving the discourse into an area where there is international agreement. ${ }^{35}$ Geoffrey Levitt argues that on a practical level, a single definition is more convenient, neater, and more efficient. ${ }^{36}$ However,

30 ibid 109.

31 ibid 97.

32 ibid 97.

33 C Walter, 'Defining Terrorism in National and International Law' (Paper presented at the Max Planck Society Conference on Terrorism as a Challenge for National and International Law, Heidelberg, 24 January 2003) <https:/www.unodc.org/tldb/bibliography/Biblio_Terr_Def_ Walter_2003.pdf> 10.

See eg F de Londras, 'Terrorism as an International Crime' in W Schabas and N Bernaz (eds), Routledge Handbook of International Criminal Law (Routledge 2010) 167, 167.

34 B Golder and G Williams, 'What is “Terrorism" Problems of a Legal Definition' (2004) 27(2) UNSWLJ 270, 288.

35 See AP Schmid, 'The Response Problem as a Definition Problem' (1992) 4(4) Terrorism and Political Violence 7.

36 Levitt (n 28) 110. 
Levitt also suggests that this practical reason alone is not sufficient to justify a deductive approach to defining terrorism. Furthermore, Levitt concedes that 'it may also be possible to employ a multi-definitional approach in a way that is convenient, neat, and efficient'. ${ }^{37}$ Levitt instead concludes that it is the moralpolitical benefits of a single definition of terrorism that is the true reason that underlies such an approach, echoing the concerns of RR Baxter that there is no real necessity for a single 'deductive' definition of terrorism. ${ }^{38}$ Referring to the quest for a single definition of terrorism in international law as distinct from a domestic legal system, Levitt argues that:

A multilateral anti-terrorism legal instrument based on a generic definition of terrorism would in effect put the official international seal of disapproval on the whole range of violent political behaviour, with a moral emphasis that the facially apolitical inductive approach lacks. Those who engage in such behaviour would be effectively branded as international outlaws. ${ }^{39}$

While Levitt is referring to efforts to define terrorism in an international context, the advantages to be gained from a single definitional approach are nevertheless transposable into the domestic context: the political benefit to be gained from having such a delegitimizing label that is 'terrorism' at the disposal of the government. Caleb Carr also agrees with this assertion, arguing that a single definition of terrorism is necessary in law in order to expose it for what it is: a belligerent activity. ${ }^{40}$ Carr embraces this moral political benefit of having a delegitimizing label at the disposal of decision makers:

It must be [broad], if we are to recognise and expose terrorism in every one of its guises and permutations, and thus reveal two truths: first, that terrorism is among mankind's most outrageously unacceptable belligerent practices, which include piracy, slavery, and genocide; and second, that every people and nation has, at one time or another, practiced a form of warlike behaviour that easily fits the definition cited above. It is only by recognizing such globally generalized responsibility for terrorism's development that we can hope to end the cyclical pattern of atrocity, accusation, rationalisation, recrimination, and revenge that has allowed the practice to remain alive. ${ }^{41}$

Thus Carr's exposing of the delegitimizing effect of the 'terrorist' label is not done in order to give the State a weapon with which it can attach to its political opponents, but also to reveal the delegitimizing actions of States themselves.

Carr's argument assumes that defining what terrorism is can frame our understanding and perspectives of it. A similar argument is put forward by Ben Saul who contends that a single definition of terrorism in international

37 ibid 109-10

38 ibid 110-11, 115; RR Baxter, 'A Skeptical Look at the Concept of Terrorism' (1974) 7 AkronLRev 380, 380.

39 ibid 111.

40 C Carr, 'Why the Definition of Terrorism Must be Broad' (2007) 24(1) World Policy Journal $47,47$.

41 ibid 48. 
law is necessary in order that the definition can be controlled. ${ }^{42}$ Golder and Williams, by arguing that law should define terrorism so as to circumscribe it within the rule of law and feed into public discourse, also appear to advance this argument of control. ${ }^{43}$ Definitions, in order to be effective, must exclude certain phenomena from their ambit, thus ensuring parameters around concepts and managing its use. A single legal definition of terrorism can potentially help shape how the term is used by both national and international actors. Indeed, one of the key concerns driving the quest for a definition of terrorism in international law is this desire to control its use. Rumyana Grozdanova suggests that the litmus test for an effective definition of terrorism in international law would be to 'limit the scope for a political, rather than legal determination of what is 'terrorism' and who is a 'terrorist'. ${ }^{44}$ A single definition of terrorism may help to confront this subjective nature of labelling an individual or event as terrorist as the labeller is simply applying the legal definition of terrorism to the facts at hand. As we shall see below, however, this argument over-estimates the capacity of legal terms to 'frame' political, public, and media debate surrounding terrorist events. ${ }^{45}$

\section{The Definition of Terrorism in UK Law}

The quest to provide a single definition of terrorism in the UK finds its origins in the recommendations made by Lord Lloyd in his 1996 Inquiry into Legislation against Terrorism report. ${ }^{46}$ Lord Lloyd's report was produced at a time when the main definition of terrorism in UK law was contained in the Prevention of Terrorism (Temporary Provisions) Act 1974 (PTA). Section 14(1) of the PTA 1974 defined terrorism as 'the use of violence for political ends, and includes any use of violence for the purpose of putting the public or any section of the public in fear.' ${ }^{7}$ The PTA 1974, motivated by the conflict in Northern Ireland and in particular the threat posed by the IRA, only covered acts of domestic terrorism. Lord Lloyd, concerned by this distinction between domestic and international terrorism proposed that any new legislation should contain a definition which covered all forms of terrorism. He then recognized the difficulties in providing just a single definition of terrorism, noting that he was aware of 'at least four different definitions of terrorism' in US law. ${ }^{48}$ Nevertheless, he then went on to recommend the following definition as used by the FBI as a template for which a UK definition could be based upon:

42 B Saul, 'Defining “Terrorism” to Protect Human Rights' in D Staines (ed), Interrogating the

War on Terror: Interdisciplinary Perspectives (Cambridge Scholars Press 2007) 190, 210.

43 See (n 34).

44 R Grozdanova, “"Terrorism” - Too Elusive a Term for an International Legal Definition?' (2014) 61(3) NILR 305, 315.

45 See (n 142).

${ }^{46}$ Lord Lloyd, Inquiry into Legislation against Terrorism: Volume 1 (TSO 1996) 24 Netherlands International Law Review 6.

47 Prevention of Terrorism Act 1974, section 14(1). $\quad{ }^{48}$ Lloyd (n 46) 26. 
The use of serious violence against persons or property, or the threat to use such violence, to intimidate or coerce a government, the public or any section of the public, in order to promote political, social or ideological objectives. ${ }^{49}$

The difficulty with using this definition, however, as Clive Walker highlights, is that the FBI definition is 'an administrative construct for jurisdictional, budgetary and other administrative purposes. It does not serve as a legal term or art on which liberty depends. ${ }^{50}$ Lord Lloyd's report thus does not go into any great detail as to why only a single definition of terrorism is needed and does not look at the underlying purpose of the FBI definition recommended.

The definition proffered by Lord Lloyd is decontextualized from the specific purpose it was designed for; it is one of a number of different definitions in US law. These definitions are of varying breadths, particular to the specific purpose of the legal source which contains them. Nicholas Perry, criticizing this piecemeal, multi-definitional approach describes this as amounting to an expression of inconsistency. ${ }^{51}$ A single definition, according to Perry, would allow for better communication between law enforcement and intelligence agencies thus improving the operational efficiency of counterterrorist powers. ${ }^{52}$ Again, however, this justification is absent from Lord Lloyd's report. As is consideration of arguments similar to Levitt's discussed above that a multidefinitional approach could be deployed 'in a way that is convenient, neat, and efficient'. ${ }^{53}$ Instead, Lord Lloyd's report starts at the point at which a general definition should be provided and then seeks to expand it to provide a general definition applicable to domestic and international terrorism.

\section{S1 Terrorism Act 2000}

The result of Lord Lloyd's report was the Terrorism Act 2000 (2000 Act) and the definition of terrorism contained in section 1 . This was subsequently amended twice by Terrorism Act 2006 and the Counter-Terrorism Act 2008 and today reads as follows:

(1) In this Act 'terrorism' means the use or threat of action where -

(a) the action falls within subsection (2) [outlined below]

(b) the use or threat is designed to influence the government or an international governmental organization or to intimidate the public or a section of the public, and

(c) The use or threat is made for the purpose of advancing a political, religious or ideological cause.

49 ibid.

50 C Walker, Blackstone's Guide to The Anti-Terrorism Legislation (Oxford University Press 2002) 21.

51 NJ Perry, 'The Numerous Federal Legal Definitions of Terrorism: The Problem of Too Many Grails' (2004) 30(2) Journal of Legislation 249, $269 . \quad 52$ ibid $272 . \quad 53$ See (n 37). 
(2) Action falls within this subsection if it -

(a) involves serious violence against a person,

(b) involves serious damage to property,

(c) endangers a person's life, other than that of the person committing the action,

(d) creates a serious risk to the health or safety of the public or a section of the public, or

(e) is designed seriously to interfere with or seriously disrupt an electronic system.

Finally, section 1.1(3) states that:

The use or threat of action falling within subsection (2) which involves the use of firearms or explosives is terrorism whether or not subsection (1)(b) is satisfied.

The UK's approach to defining terrorism therefore is a deductive one: it starts out with an initial statement and then applies it to a broad array of crimes, inchoate offences, police and immigration powers, and as a guide for prosecutorial discretion.

This definition was itself the subject of a comprehensive review by the then Independent Reviewer of Terrorism Legislation Lord Carlisle undertaken at the request of the then Home Secretary. ${ }^{54}$ Lord Carlisle identified four alternative propositions that could be followed to reform section 1 , all of which he rejected. First, that no definition of terrorism is needed, nor any special procedures required. Second, that a definition is needed but no special procedures and offences required; rather, adjustment to the sentencing powers would suffice. Third, that a definition is needed, including special procedures and offences but that the definition ought to be tighter than at present. Finally, that a definition is needed, including special procedures and offences, drawn broadly and to anticipate estimates of future terrorism activity. ${ }^{55}$ What is common to these propositions is that they all assume a single definitional approach. Even the first argument that rejects outright the need to define terrorism is framed in terms critical of a single definition of terrorism. Thus Lord Carlisle, like Lord Lloyd before him, exercises no critical analysis of the merits of a multi-definitional approach, assuming that the choices are either a single definition of terrorism or none at all.

\section{THE SINGLE DEFINITION OF TERRORISM AND THE PRINCIPLE OF LEGALITY}

The UK's 'one size fits all' definition of terrorism, pursued without much thought into the actual advantages and disadvantages of a single definitional approach, is one of substantial breadth which poses considerable difficulties for the rule of law. This is ironic seeing as one of the primary justifications

54 Lord Carlisle, ‘The Definition of Terrorism' (Cm 7052, March 2007).

55 ibid 19. 
for a single definition of terrorism is that it can provide clarity and certainty in a way that a multi-definitional approach cannot. ${ }^{56}$ Like the notion of terrorism, the rule of law is itself an incredibly broad concept, lacking comprehensive agreement as to its scope. ${ }^{57}$ At a minimum, however, the rule of law requires the principle of legality: that law should be ex ante promulgated in a clear manner, so that individuals may be certain that their conduct is in conformity with it. ${ }^{58}$ These elements of clarity and certainty are evident in even the thinnest conceptions of the rule of law. Clarity and certainty appear in Dicey's formulation of the rule of law, ${ }^{59}$ and indeed in Carl Schmitt's conception of law. ${ }^{60}$ Thus Schmitt's argument that states of exception cannot be circumscribed by law due to the inability of law to prescribe ex ante the possible conditions that may warrant the ushering in of a state of exception is a testament to this. Clarity and certainty also have a degree of normative value to them, even if the law that they refer to is one that would be abhorrent to most standards of morality or judicial cultures today. ${ }^{61}$

Section 1's conformity with the principle of legality was raised by the Supreme Court in $R v$ Gul. ${ }^{62}$ The defendant in that case had been convicted under section 2 of the Terrorism Act 2006 for dissemination of terrorist publications. The defendant had uploaded onto YouTube:

(i) attacks by members of Al-Qaeda, the Taliban, and other proscribed groups on military targets in Chechnya, and on the Coalition forces in Iraq and in Afghanistan, (ii) the use of improvised explosive devices ('IEDS') against Coalition forces, (iii) excerpts from 'martyrdom videos', and (iv) clips of attacks on civilians, including the 9/11 attack on New York. These videos were accompanied by commentaries praising the bravery, and martyrdom, of those carrying out the attacks, and encouraging others to emulate them. ${ }^{63}$

Whether Gul had uploaded 'terrorist publications' thus depended upon whether the individuals in the videos in question were engaged in terrorist activity. Gul attempted to argue on three separate grounds that the definition of terrorism contained in section 1 of the 2000 Act should be read down:

56 Walter (n 33).

57 See Bingham (n 2); B Tamanaha, On The Rule of Law: History, Politics, Theory (Cambridge University Press 2007); P Craig, 'Formal and Substantive Conceptions of the Rule of Law: An Analytical Framework' [1997] PL 567.

58 L Fuller, The Morality of Law (Yale University Press 1969) 74.

59 AV Dicey, Introduction to the Study of the Law of the Constitution (6th edn, Macmillan and Co 1902) 183-4.

${ }^{60}$ See C Schmitt, Political Theology: Four Chapters on the Concept of Sovereignty (Schwab G trans, University of Chicago Press 2005); JP McCormick, 'The Dilemmas of Dictatorship: Carl Schmitt and Constitutional Emergency Powers' (1997) 10 CJLJ 163, 169.

61 Thus the Code of Hammurabi reflected at a minimum level of a formal concept of the rule of law. By prescribing an 'eye for an eye' the punishment is known before an individual conducts their affairs. See R Pound, 'The End of Law as Developed in Legal Rules and Doctrines' (1914) 27(3) HarvLRev 195, 199.

${ }^{62} R v$ Gul [2013] UKSC 64. See also A Greene, 'The Quest for a Satisfactory Definition of Terrorism: $R v$ Gul' (2014) 77(5) MLR 780. 
i. The 2000 Act, like the 2006 Act was intended, at least in part, to give effect to the UK's international treaty obligations and therefore the concept of terrorism in the 2000 Act should accord to the concept of terrorism in international law which does not extend to military acts by a non-state armed group against a state or IGO [Inter-governmental Organization]. ${ }^{64}$

ii. That it would be wrong to read the 2000 and 2006 Acts as criminalising in the UK an act abroad, unless that act would be regarded as criminal by international law. ${ }^{65}$

iii. As a matter of domestic law, as distinct from international law, some qualifications must be read into the very wide words of section 1 of the 2000 Act. $^{66}$

The Supreme Court rejected all three arguments. Arguments (i) and (ii) are based on international law and were dismissed as imposing any limit on the breadth of section 1 with the Supreme Court concluding that there was no rule that precluded the UK from going beyond what was required by international law so long as it did not drop below the minimum agreed upon. ${ }^{67}$ Argument (i) is particularly problematic as there is no clear definition of terrorism in international law. ${ }^{68}$ The disagreement regarding the status of freedom fighters in international law fell far short of a 'general understanding of what terrorism was' and indeed is the key stumbling block for the question for a single definition of terrorism in international law. ${ }^{69}$

Argument (iii) instead was based on domestic law, with counsel urging the Court to read some qualifications into section 1 so as to narrow its breadth. The Government submitted that the common sense usage of discretion by the Crown Prosecution Service (CPS) could justify in law the breadth of section $1 .{ }^{70}$ While the Independent Reviewer of Terrorism Legislation David Anderson (the Independent Reviewer) believes that the operation of prosecutorial discretion can mitigate the negative effects of the breadth of section $1,{ }^{71}$ the Supreme Court expressly rejected this in Gul:

It may well be that any concern which Parliament had about the width of the definition of terrorism in section 1(1) was mitigated by the existence of the statutory prosecutorial discretion but ... we do not regard it as an appropriate reason for giving 'terrorism' a wide meaning. ${ }^{72}$

This lack of clarity leaves an individual uncertain as to whether their actions will be retrospectively described as terrorist, leaving a temporal gap between their actions and their subsequent labelling as terrorist. ${ }^{73}$ Thus reliance upon prosecutorial discretion, while de facto may alleviate some of the fears regarding the breadth of section 1; de jure it is not acceptable. The Supreme Court stated that Parliament had essentially abdicated its responsibility to an unelected official of the executive. ${ }^{74}$

\footnotetext{
64 ibid [24]. $\quad 65$ ibid. $\quad 66$ ibid. $\quad 67$ ibid [53]. $\quad 68$ ibid [18].

${ }_{73} \mathrm{See}$ (n 23). $\quad{ }^{70} \mathrm{Gul}$ (n 62) [30]; Greene (n 62) 783. $\quad{ }^{71}$ ibid at [40]. $\quad{ }^{72}$ ibid 15 at [40].

73 Greene (n 62) $785 . \quad{ }^{74}$ Gul (n 62) [26].
} 
British courts can legitimately engage in an interpretive exercise that assumes Parliament intended to legislate in conformity with fundamental constitutional principles such as the rule of law. ${ }^{75}$ This has resulted in some high-profile instances where courts have creatively interpreted statutory provisions to what would be in the eyes of some commentators the apparent contrary of what Parliament intended. ${ }^{76}$ Nevertheless, despite this capacity for courts to vindicate the principle of legality and the strong concerns regarding the reliance on prosecutorial discretion to curtail the breadth in section 1 , the Supreme Court could find no indication in the words laid down by Parliament that they intended anything other than this outcome. As a result of $G u l$, the breadth of section 1 was left untempered.

While Gul ultimately lost his case, the Supreme Court nevertheless expressed a powerful obiter dictum regarding the scope of the definition of terrorism contained in section 1:

While acknowledging that the issue is ultimately one for Parliament, we should record our view that the concerns and suggestions about the width of the statutory definition of terrorism which Mr Anderson has identified in his two reports merit serious consideration. Any legislative narrowing of the definition of 'terrorism', with its concomitant reduction in the need for the exercise of discretion under section 117 of the 2000 Act, is to be welcomed, provided that it is consistent with the public protection to which the legislation is directed. ${ }^{77}$

The second general point is that the wide definition of 'terrorism' does not only give rise to concerns in relation to the very broad prosecutorial discretion bestowed by the 2000 and 2006 Acts. The two Acts also grant substantial intrusive powers to the police and to immigration officers, including stop and search, which depend upon what appears to be a very broad discretion on their part. While the need to bestow wide, even intrusive, powers on the police and other officers in connection with terrorism is understandable, the fact that the powers are so unrestricted and the definition of 'terrorism' is so wide means that such powers are probably of even more concern than the prosecutorial powers to which the Acts give rise. ${ }^{78}$

\section{A. The Definition of Terrorism and the Principle of Legality in ECHR Jurisprudence}

This concern of the Supreme Court regarding the principle of legality in the context of stop and search powers is echoed by the European Court of Human Rights (ECtHR). The principle of legality is expressly enumerated in

75 See M Elliott, The Constitutional Foundations of Judicial Review (Hart Publishing 2001) ch 4 .

76 See Anisminic v Foreign Compensation Commission [1969] 2 AC 147; $R$ v Evans [2015] UKSC 21. $\quad 7_{77}$ Gul (n 62) at [62]. 
a number of Convention articles requiring that measures which infringe upon qualified rights in order to give effect to a pressing social need must do so in a manner 'prescribed by law'. The prohibition on retrospective criminal punishment, for example, is enumerated in Article 7 and is given nonderogable status. ${ }^{79}$ Article 7 is, however, rarely considered by the ECtHR and instead more common challenges to criminal offences tend to arise under Article 5 (right to liberty) and Article 6 (right to a fair trial). ${ }^{80}$ Under Article 5 (1) of the ECHR, for example, any restriction on liberty must be 'in accordance with a procedure prescribed by law'. An illustrative example of this is contained in Article 5(1)(c) of the Convention which permits the lawful arrest of a person on the grounds of reasonable suspicion that they have committed and offence. 'Offence' in this paragraph has an autonomous Convention meaning and so the mere fact that a contracting State has labelled a certain provision of its criminal law as an 'offence' will not be conclusive. ${ }^{81}$

In Brogan v UK, the ECtHR found that the then UK definition of terrorism contained in the Prevention of Terrorism Act 1984 (PTA 1984) - the use of violence for political ends, and includes any use of violence for the purpose of putting the public or any section of the public in fear-was 'well in keeping with the idea of an offence.' 82

To corroborate this, the Court in Brogan cited paragraph 196 of its judgment in Ireland $v U K .{ }^{83}$ Paragraph 196, however, merely repeats the phrase 'well in keeping with the idea of an offence' and cross-cites back to paragraphs 85-88 of itself. Paragraphs $85-88$ of Ireland $v U K$ do not, however, yield any other authority to corroborate this confident assertion that the definition of terrorism in question is 'well in keeping with the idea of an offence'. Instead, these paragraphs contain a descriptive discussion of the domestic legal provisions relevant to Ireland $v U K$ and their origins. Paragraph 85 draws attention to the Terrorists Order which was a ministerial order passed by the Secretary of State for Northern Ireland in accordance with the Northern Ireland (Temporary Provisions) Act 1972. The Terrorists Order defined terrorism as 'the use of violence for political ends, [including] any use of violence for the purpose of putting the public or any section of the public in fear'; ie it was the definition that was subsequently contained in the PTA 1984. There is no substantive analysis of why this definition is 'well in keeping with the idea of an offence'. At best, Brogan reveals a very thin 'rule by law' approach to the meaning of 'offence', with the ECtHR's reasoning wholly reliant upon the fact that that the law in question is enumerated in a statute and ministerial order. There is no substantive analysis of the actual

79 Art 15.2 ECHR.

80 See DJ Harris, M O'Boyle, EP Bates and CM Buckley, Law of the European Convention on Human Rights (2nd edn, Oxford University Press, 2009) ch 10.

${ }_{81}$ ibid; Engels $v$ Netherlands A 22 (197) EHRR 706.

82 Brogan v UK A 145-B (1988) 11 EHRR 117 PC, para. 51.

83 Ireland $v$ United Kingdom A 25 (1978) 2 EHRR 25. 
text in question and its conformity with the principle of legality. The ECtHR therefore has never actually attempted to unpack whether the definition of terrorism in the PTA 1984 is 'well in keeping with the idea of an offence'. Instead, it repeats this phrase until it becomes a self-justifying loop.

A further problem with relying upon paragraph 85 of Ireland $v U K$ as an authority for a definition of terrorism being 'well in keeping with the idea of an offence' is that this case explicitly states that that the Terrorist Order in question was subject to a notice of derogation under Article 15 of the ECHR made by the UK government on 23 January $1973 .{ }^{84}$ The entire purpose of declaring an emergency and derogating from the Convention is to take measures that are ordinarily not permitted under the ECHR. ${ }^{85}$ It is not correct to assert that the Terrorist Order subject to derogation under Article 15 is compliant with the ordinary scope Convention as it operates in normalcywhen an emergency has not been declared. The authority of Ireland $v U K$ pertaining to the definition of terrorism should be 'quarantined' to when an emergency is declared under Article 15. In Brogan, no such derogation was in effect. ${ }^{86}$ However, even such a restriction is itself overly broad as each emergency experienced by a State or by different States may be different and so what may be 'proportionate to the exigencies of the situation' in one emergency may not be so in another. Consequently, the Court's reliance upon Ireland $v U K$ as an authority for the statement that the definition of terrorism contained in the PTA 1984 is, at its most generous reading, weak; at worst it is simply mistaken.

One must, of course, look at the substantive elements of a particular definition to assess whether it is 'well in keeping with the idea of an offence'. In this regard, the definition of terrorism in the PTA 1984 is noticeably narrower than that contained in section 1 of the 2000 Act. ${ }^{87}$ It referred only to 'the use of violence for political ends', whereas section 1 refers to the 'use or threat of action'. Action is defined in section 1(2) as something which is not necessarily physical violence against a person or property but can include an action that puts others at risk or can 'seriously to interfere with or seriously disrupt an electronic system'. Moreover, in Brogan, the offences delineated were scheduled offences. The petitioners were charged with the more narrowly defined membership of a prescribed organization as distinct from being involved in terrorism more generally.

In contrast to Brogan, more recent cases suggest that the ECtHR is engaging in closer scrutiny of whether State measures taken in the name of national

84 ibid para 85; 16 Yearbook of the Convention, 24-6.

85 See A Greene, 'Separating Normalcy from Emergency: The Jurisprudence of Article 15 of the European Convention on Human Rights' (2011) 12(10) German Law Journal 1764; O Gross and F Ní Aoláin, 'From Discretion to Scrutiny: Revisiting the Application of the Margin of Appreciation Doctrine in the Context of Article 15 of the European Convention on Human Rights' (2001) 3 HumRtsQ 623.

${ }^{86}$ Brogan (n 82) [48].

87 See (n 47). 
security are 'prescribed by law'. In Gillan and Quinton $v U K$, police stop and search powers under section 44 of the Terrorism Act 2000 were found by the ECtHR to be incompatible with the right to privacy in Article $8 .{ }^{88}$ Such stop and search powers were, according to the Court not 'prescribed by law'. Finding that the rule of law 'is inherent in the object and purpose of Article 8 and expressly mentioned in the preamble to the convention', ${ }^{89}$ the Court held that '[T] he law must thus be adequately accessible and foreseeable, that is, formulated with sufficient precision to enable the individual — if need be with appropriate advice — to regulate his conduct.' ${ }^{90}$ However, while the definition of terrorism in section 1 of the 2000 Act is relevant for the operation of section 44 stop and search powers, the judgment of the ECtHR in Gillan did not address this issue. Instead, it was specific failures of section 4 that made it fall foul of the rule of law. Gillan thus illustrates the difficulties in trying to challenge section 1's conformity with the principle of legality as courts will tend to home in on the specific power or offence in question, rather than the definition of terrorism in the abstract. Cases such as Gul, where the particular facts of the case meant that the definition's scope had to be directly addressed will be rare. ${ }^{91}$

\section{B. The Principle of Legality and the Application of UK Terrorism Legislation Overseas}

Challenges to the principle of legality by the operation of decision-maker discretion are particularly heightened in the context of the application of UK counterterrorism legislation overseas. A State on the domestic level does not have to deal with the geopolitical wrangling of whether there is a distinction between 'terrorist' and 'freedom fighter' and so is free to define terrorism in line with its subjective perspectives on the issue. Whether the lack of such a distinction exists in UK domestic law, however, depends upon the interpretation of the word 'government' in section 1(b) of the 2000 Act. Section 1(4)(d) defines 'government' to mean 'the government of the United Kingdom, a Part of the United Kingdom or of a country other than the United Kingdom'. 92

Despite this clarification, there is still room for interpretation. In $R v F$, the Court of Appeal upheld the Appellant's conviction for possession of a document or record containing information of a kind likely to be useful to a

88 Gillan and Quinton $v$ United Kingdom ECtHR 12 January 2010.

89 ibid [76].

90 ibid, quoting $S$ and Marper v United Kingdom [2008] ECHR 1581.

91 See text to 122 below for a discussion of Miranda $v$ SSHD where the Court of Appeal issued a declaration of incompatibility against schedule 7 of the 2000 Act which permits stop and search powers of individuals suspected of terrorism at UK borders.

92 Terrorism Act 2000, section 1(4)(d). 
person committing or preparing an act of terrorism. ${ }^{93}$ The material in question included a CD with material downloaded from a Jihadist website, containing instructions regarding the manufacturing of explosive devices. ${ }^{94}$ The appellant was also in possession of a document detailing how to set up a 'terrorist cell'. ${ }^{95}$ The appellant argued, however, that he did not intend to attack the UK but instead attack the Libyan government of Muammar Gaddafi. He therefore argued that the meaning of 'government' in section 1 of the 2000 Act should be read compatibly with the ECHR by using the Court's interpretive obligation under section 3 of the Human Rights Act 1998 so as to exclude dictatorships or military junta. ${ }^{96}$ The Court of Appeal rejected this argument stating that '[I]n our judgment the meaning of the phrase- - "a country other than the United Kingdom”- -is plain enough.' The Court added:

We can see no reason why, given the random impact of terrorist activities, the citizens of Libya should not be protected from such activities by those resident in this country in the same way as the inhabitants of Belgium or the Netherlands or the Republic of Ireland. More important, we can see nothing in the legislation which might support this distinction. ${ }^{97}$

This approach has a number of difficulties attached to it, however; as identified by the Court of Appeal:

What is striking about the language of s[ection] 1, read as a whole, is its breadth. It does not specify that the ambit of its protection is limited to countries abroad with governments of any particular type or possessed of what we, with our fortunate traditions, would regard as the desirable characteristics of representative government. There is no list or schedule or statutory instrument which identifies the countries whose governments are included within s[ection]1(4)(d) or excluded from application of the Act. Finally, the legislation does not exempt nor make an exception, nor create a defence for, nor exculpate what some would describe as terrorism in a just cause. Such a concept is foreign to the Act. Terrorism is terrorism, whatever the motives of the perpetrators. ${ }^{98} \ldots$

It was however open to Parliament to decide that because of the evils of terrorism and the manifold dangers that terrorist activities create, it should impose a prohibition on the residents of this country from participating or seeking to participate in terrorist activities, which may have a devastating impact wherever in the world they occur. ${ }^{99}$

According to the Court of Appeal, section 1 of the 2000 Act makes no distinction between terrorist and freedom fighter. The problem with this approach, however, as suggested by Ben Saul, is that it negates any incentive for a nonState belligerent to comply with international humanitarian law. ${ }^{100}$

$93 \quad R v F$ [2007] QB 960; Terrorism Act 2000, section 58(1)(b).
96 ibid [6].

100 B Saul, 'Terrorism as a Legal Concept' in G Lennon and C Walker (eds), Routledge Handbook of Law and Terrorism (Routledge 2015) ch 3; Sydney Law School Research Paper No 15/85 available at SSRN <http://ssrn.com/abstract=2664404>9. 
An additional issue not addressed by the Court of Appeal in $R v F$ is the effect of UK government recognition of whom the legitimate authority of a State is. $R$ $v F$ was decided before UK military intervention in Libya where NATO forces gave military support to armed groups seeking to oust the Gaddafi regime. In 2011, UN Security Council Resolution 1973 authorized the enforcement of a no-fly zone in Libya for the express purposes of protecting civilians. ${ }^{101}$ This resolution was enforced by NATO with the UK playing a major role in 'Operation Unified Protector'. ${ }^{102}$ According to the literal meaning of Resolution 1973, it did not, however, authorize 'regime change'. While the resolution does state that it authorized 'all necessary measures,' Olivier Corten and Vaios Koutroulis argue that this cannot be used to justify regime change. ${ }^{103}$ Firstly, while 'all necessary measures' has become the standard terminology in international law for permitting the use of force, in this instance it was followed by the phrases 'to protect civilians and civilian populated areas under threat of attack in the Libyan Arab Jamahiriya' and 'to enforce compliance with the ban on flights'. 'All necessary measures' therefore was not a carte blanche grant of discretion but was clarified to require these measures be directed towards a specific objective only. ${ }^{104}$ This is further corroborated by the general principle in international law that there is no norm permitting a State to support an armed rebel group in the overthrow of a government, even if that said government was guilty of gross human rights violations. ${ }^{105}$ Finally, General Assembly Resolution 2625 (XXV) which reflects general customary international law affirmed that support to rebels falls under the prohibition of the use of force. ${ }^{106}$ Consequently, Security Council Resolution 1973 could not be used as a legal basis for regime change in Libya.

Despite this strong prohibition against using military support to effect regime change in international law, the NATO campaign diverged dramatically from its initial objective of enforcing a no-fly zone to one which had the clear purpose of effecting a regime change. ${ }^{107}$ The UK Government therefore gave military support to armed groups that would satisfy the UK definition of terrorism. The extraterritorial application of section 1 means that individuals fighting for such groups in Libya could be guilty of terrorist offences in UK domestic law and thus liable for prosecution. During this military campaign, France, the UK and other NATO members officially recognized the Libyan Transnational National Council (TNC) as the legitimate authority of

\footnotetext{
101 UNSC Res 1973 (17 March 2011) UN Doc S/RES/1973.

102 See NATO, 'Operation UNIFIED PROTECTOR: Final Mission Stats' (2 November 2011) <http://www.nato.int/nato_static/assets/pdf/pdf_2011_11/20111108_111107-factsheet_up_ factsfigures_en.pdf $>$.

103 O Corten and V Koutroulis, 'The Illegality of Military Support to Rebels in the Libyan War: Aspects of jus contra bellum and jus in bello’ (2013) 18(1) JC\&SL 59.

105 ibid 71-3.

106 ibid 65; UN General Assembly (UNGA) Res 2625 (XXV) (24 October 1970);

107 Corten and Koutroulis (n 103) 71-3.
} 
Libya. ${ }^{108}$ The recognition of the TNC as the legitimate authority of Libya by member of the coalition of the willing did not affect the legality under international law of the military support for the rebels; however, whether such an argument could influence the interpretation of section 1 is unclear. In addition, throughout the conflict, Libyan rebel groups were accused of a number of breaches of international humanitarian law. ${ }^{109}$ Therefore, even if the UK definition of terrorism were amended so that it would not cover armed groups that abide by international humanitarian law, the Libyan rebels would have failed to satisfy this.

\section{Prosecutorial Discretion and British combatants in non-international armed conflicts}

$R v F$, decided in 2007, contains some prophetic statements pertaining to UK intervention in non-international conflicts that erupted from the Arab Spring:

If it were ever permissible to visit terrorist activities on a tyrannical government, would that immunity extend to a group seeking by violent means to foist its own different but equally undemocratic principles on the country whose tyrant was overthrown? ${ }^{110}$

Thus if the UK definition of terrorism were to exclude attacks against, for example, the Syrian government of President Bashar al-Assad and the ruling Ba'ath Party, this would apply to all those who perpetrated such attacks, including so-called Islamic State (ISIS), or their known associates. The complexities and contradictions of this approach are numerous. In September 2013, Parliament refused to give consent to UK military intervention in Syria against the Assad regime following the alleged use of chemical weapons in Ghouta, Syria. ${ }^{111}$ This intervention would have directly and indirectly aided all armed groups opposed to the Assad regime. Each and every one of these opposition groups would satisfy the UK domestic definition of terrorism. Two years later in December 2015, Parliament affirmed the Government's request to launch airstrikes in Syria, not against the Assad regime but against ISIS a terrorist organization which constitutes an 'unprecedented threat to international peace and security'. ${ }^{112}$

The UK officially recognized the 'Syrian National Coalition' (SNC) as the country's legitimate government back in 2012; but once again this cannot affect the legality of military support for such a rebel grouping according to

108 See S Talmon, 'Recognition of the Libyan National Transitional Council' (2011) 15(16) ASIL Insights < https://www.asil.org/insights/volume/15/issue/16/recognition-libyan-nationaltransitional-council>; 'Libya: France Recognises Rebels as Government' (BBC News, 10 March $2011)<$ http://www.bbc.com/news/world-africa-12699183>; 'Britain Recognises Libyan Rebels as Legitimate Government' (CNN News, 27 July 2011) <http://edition.cnn.com/2011/WORLD/ europe/07/27/uk.libya.embassy/>. $\quad 109$ Corten and Koutroulis (n 103) 87-90. ${ }_{110}^{110} R$ F (n 93) [30]. $\quad{ }^{111}$ HC Deb 29 Aug 2013, vol 566, cols 1426-1556.

112 HC Deb2 Dec 2015, vol 603, cols 323-500. 
international law. ${ }^{113}$ The UK's support for the SNC and other Syrian opposition groups extends beyond military (humanitarian) assistance to include 'over $£ 45$ million of non-humanitarian aid in response to the Syria conflict. $£ 2$ million of this has gone directly to fund the SNC' ${ }^{114}$ An absurd example of this clash between the legal definition of terrorism and the political reality is the case of Bherlin Gildo, a Swedish national accused of terrorist activities in Syria; however, the case against him collapsed when it became clear that British security and intelligence agencies were supporting the group he was affiliated with. ${ }^{115}$

This difficulty therefore is not merely one of a political complaint about the hypocritical disjuncture between domestic law and the UK government's practice overseas but gives rise to genuine legal difficulties concerning the principle of legality in the context of prosecuting British citizens or residents who were belligerents in non-international conflicts who have subsequently returned home to the UK. When the Crown Prosecution Service (CPS) decides to prosecute a person, it does so based on whether there is a sufficiently strong case against a person and whether it is in the public interest to bring the prosecution forward. ${ }^{116}$ Under the 2000 and 2006 acts, the CPS must seek the consent of the Attorney General before prosecutions may be brought against individuals for terrorist offences committed outside the UK. ${ }^{117}$ This requirement is in place in order to prevent compromising both British and foreign intelligence operations. It may be the case that the CPS, in its discretion, is only deciding to prosecute combatants returning to the UK that pose a threat to the UK itself. Alternatively, it may take the position that it is in the public interest to deter individuals from travelling abroad to fight in armed conflict and so may decide to prosecute whether or not the individual poses a threat to the UK. Either way, the issue is not settled by the fact that the UK definition of terrorism makes no formal distinction between terrorist and freedom fighter. Rather, this broad conflation of the two in UK law results in prosecutors, and the Attorney General making this decision and exercising vast discretion as they do so.

113 R Spencer and R Sherlock, 'Britain officially recognises new Syrian rebel coalition as country's “legitimate” government' The Telegraph (20 November 2012) < http://www.telegraph. co.uk/news/9691319/Britain-officially-recognises-new-Syrian-rebel-coalition-as-countryslegitimate-government.html>.

114 'UK Non-Humanitarian Aid in Response to the Syria Conflict' < https://www.gov.uk/ government/uploads/system/uploads/attachment_data/file/371647/Syria_UK_Non-Humanitarian_ Support_-_Public_document_3_Apr__3_pdf $>1$.

${ }_{15} \mathrm{R}$ Norton-Taylor, 'Terror Trial Collapses after Fears of Deep Embarrassment to Security Services' The Guardian (1 June 2015) <http://www.theguardian.com/uk-news/2015/jun/01/trialswedish-man-accused-terrorism-offences-collapse-bherlin-gildo $>$ KJ Heller, 'British Government says “Oops, Our Bad” in Terrorism Case' (Opinio Juris, 7 September 2015) <http://opiniojuris. org/2015/09/07/uk-government-says-oops-our-bad-in-terrorism-case/>.

116 Crown Prosecution Service, 'The Code for Crown Prosecutors' (January 2013) <https://www. cps.gov.uk/publications/docs/code_2013_accessible_english.pdf> 7-10 .

117 Terrorism Act 2000, section 117; Terrorism Act 2006, Pt I. 
The result is that the current definition of terrorism places too much discretionary power on unelected officials and, as stated by $R v G u l$, is inherently damaging to the rule of law and the principle of legality. In effect, the conflation of terrorist and freedom fighter has not resulted in the abolition of the distinction between these two concepts in Government policy. The moral judgment involved in labelling an act as terroristic is still preserved under section 1 . The breadth of section 1 means that this distinction between legitimate and illegitimate violence is being made by government officials rather than by Parliament.

\section{A MULTI-DEFINITIONAL APPROACH TO TERRORISM?}

Notwithstanding the persuasiveness of arguments discussed that terrorism is no more than a social construct amounting to political violence that the observer considers to be illegitimate, it appears that counterterrorist legislation is here to stay. Indeed, it may be the case that abandoning the concept of terrorism could be more damaging to human rights as the powers limited (albeit very broadly) by this definition would most likely remain on the statute books in some form. For example, while defining terrorism with reference to motive is problematic, this additional hurdle that the prosecution or decision maker must prove or factor into account can act as a control on the breath of the power in question. ${ }^{118}$ The solution therefore that this article advocates is a pragmatic one: if we are to include counterterrorist powers and offences in our legal system then the quest for a single definition should be abandoned. Instead a multidefinitional approach should be pursued.

From a rule of law perspective, a multi-definitional approach would have the advantage of avoiding the accommodation of the 'lowest common denominator' that afflicts the single definitional approach. A narrower definition can be used in certain instances, thus better protecting human rights and the principle of legality. At the same time, a broader definition could apply to legal norms where it is of 'operational necessity' to do so.

This more nuanced approach to defining terrorism is arguably already the case at present. In addition to section 1, the UK has one other definition of terrorism in the Reinsurance (Acts of Terrorism) Act 1993 which is specifically for the purposes of defining terrorism for insurance claims. ${ }^{119}$ More significantly, recent changes to the Terrorism Prevention and Investigation Measures Act 2011 (TPIMA) also depart from section 1. In his report on the operation of terrorism legislation in 2013, David Anderson responded to government plans to reintroduce relocation orders in TPIMs. ${ }^{120}$

118 C Walker, Terrorism and the Law (Oxford University Press 2011) 38.

119 See Reinsurance (Acts of Terrorism) Act 1993 (n 1).

120 D Anderson, 'Second Report of the Independent Reviewer on the Operation of the Terrorism Prevention and Investigation Measures Act 2011' (TSO 2014) 51-3. 
Anderson acknowledged the potential operational necessity of such a reintroduction; however, he also suggested that the broad definition of 'terrorist-related activity in the TPIMA be revisited, with a view to narrowing it. The Counter-Terrorism and Security Act 2015 gave effect to the Independent Reviewer's suggestion, reintroducing relocation orders while at the same time narrowing the definition of 'terrorist related activity' to exclude support or assistance to those who are themselves facilitating or encouraging the commission, preparation or instigation of acts of terrorism. ${ }^{121}$

\section{A. Miranda v SSHD: Towards a Multi-Definitional Approach?}

One such area in which a narrower definition of terrorism would be beneficial for both human rights and the rule of law would be in criminal offences or State powers that impact upon freedom of expression. In Miranda $v S S H D,{ }^{122}$ the applicant was detained and questioned at Heathrow airport under paragraph 2 (1) of schedule 7 of the 2000 Act. Personal items including encrypted storage devices were taken from him. The applicant was the spouse of Glenn Greenwald, the journalist who had interviewed and subsequently published in The Guardian material leaked by whistle-blower Edward Snowden regarding the activities of the US National Security Association (NSA) and their capacity to access individuals' digital data. ${ }^{123}$

Schedule 7 can be exercised when an examining officer has grounds for suspecting that an individual is a 'terrorist'. 'Terrorist' is circularly defined in section 40(1)(b) as being an individual who 'is or has been concerned in the commission, preparation or instigation of acts of terrorism'. ${ }^{124}$ Thus the scope of schedule 7 is necessarily dependent upon the definition of terrorism in section 1 of the 2000 Act.

While there was some dispute as to the purpose of the detention, the Court of Appeal, agreeing with the police, held that the purpose was to determine whether Miranda was a person falling within section 40(1)(b) of the 2000 Act, ie whether he was a terrorist under the meaning of the 2000 Act. Focus therefore centred on the meaning of section 1 . Concerns were raised as to the breadth of this definition when applied to the publication of material related to terrorism and other journalistic activities. This concern is heightened when one, as Laws LJ did at first instance, takes a literal approach to its interpretation. Laws LJ accepted the argument that:

... the section 1 definition is 'capable of covering the publication or threatened publication [for the purpose of advancing a political, religious, racial or

121 ibid 48-9.

122 [2016] EWCA Civ 6.

123 See G Greenwald, E MacAskill and L Poitras, 'Edward Snowden: The whistleblower behind the NSA surveillance revelations' The Guardian (11 June 2013) <http://www.theguardian.com/ world/2013/jun/09/edward-snowden-nsa-whistleblower-surveillance >.

${ }_{124}$ Terrorism Act 2000, section 40(1)(b). 
ideological cause] of stolen classified information which, if published, would reveal personal details of members of the armed forces or security and intelligence agencies, thereby endangering their lives, where that publication or threatened publication is designed to influence government policy on the activities of the security and intelligence agencies': section 1(1)(b) and (c), and (2)(c). ${ }^{125}$

The appellant argued that this literal interpretation was too broad as:

It would include activity that is entirely non-violent; is in pursuit of a legitimate and mainstream political cause; may 'endanger life' by accident; and where the person may be 'concerned' in such activity wholly accidentally or even without knowledge ... On this interpretation of 'act of terrorism', section 41 would allow a power of arrest, detention and questioning of any person on reasonable grounds to suspect that he was accidentally or unknowingly involved in non-violent political activity that indirectly, inadvertently and unintentionally happened to endanger life. ${ }^{126}$

A number of examples of the absurd application of this over-broad definition were given. For example, a junior doctor who erects a sign to protest about Government policy towards the NHS but inadvertently erects it in a way that accidentally endangers the life of a passer-by. ${ }^{127}$ The chilling effect that this may have on free speech was also stressed by the appellant and by the Independent Reviewer. ${ }^{128}$ Anderson gives the example of the publication of a blog that argues on religious or political grounds against the vaccination of children. If this publication were judged to create a serious risk to public health and designed to influence the government, then it would be classified as a terrorist action. ${ }^{129}$

Dyson MR, persuaded by these arguments, adopted an alternative approach to the interpretation of section 1, arguing that a mental element must be read into section 1 when it is applied in certain instances. Dyson MR parses the section 1 definition of terrorism into three distinct categories of action. The first category is defined exclusively by the action itself; the second are actions defined by their consequences; and the final is an action defined by reference to its aim. Arguing that a mental element is necessary for the first and third categories, Dyson MR concludes that although on a literal interpretation it is possible that a mental element is not necessary for the second category, it would be an anomaly if Parliament intended it to be read as so. Dyson MR therefore concludes that actions defined as terrorist by reference to their consequence must require that the individual intended or was reckless as to these consequences coming to fruition. ${ }^{130} \mathrm{He}$ therefore argues that:

\footnotetext{
125 Miranda (n 122) [41]. $\quad 126$ ibid [43]. $\quad 127$ ibid [46]. $\quad 128$ ibid [47].

129 D Anderson, 'The Terrorism Acts in 2013: Report of the Independent Reviewer on the Operation of the Terrorism Act 2000 and Part 1 of the Terrorism Act 2006' (TSO 2014) at [4.19].

${ }^{130}$ Miranda (n 122) [53]-[54].
} 
On the interpretation which I would adopt, such a blogger would not be a terrorist even if his blog were judged to create a serious risk to public health, unless he intends his publication to create the risk (or is reckless as to whether his blog will have that effect). Likewise, on this interpretation the junior doctors ... would not be terrorists either. ${ }^{131}$

Ultimately, the Court of Appeal issued a declaration of incompatibility of Schedule 7 with Article 10 of the ECHR on the grounds that it was not 'prescribed by law':

I accept that these are constraints on the exercise of the power, but in my judgment they do not afford effective protection of journalists' article 10 rights. The central concern is that disclosure of journalistic material (whether or not it involves the identification of a journalist's source) undermines the confidentiality that is inherent in such material and which is necessary to avoid the chilling effect of disclosure and to protect article 10 rights. If journalists and their sources can have no expectation of confidentiality, they may decide against providing information on sensitive matters of public interest ... It is, therefore, of little or no relevance that the schedule 7 powers may only be exercised in a confined geographical area or that a person may not be detained for longer than nine hours. ${ }^{132}$

'Obvious' solutions suggested by the court to rectify this incompatibility is 'some form of judicial or other independent and impartial scrutiny conducted in such a way as to protect the confidentiality in the material'. ${ }^{133}$ An alternative approach, and one suggested by this article, would be for a narrower definition of terrorism to trigger schedule 7 stop and search powers.

While Dyson MR's interpretation does rein in somewhat the excesses of section 1, concerns, nevertheless, remain. Dyson MR's second category of terrorist acts is based upon their consequences - the endangerment of a person's life or the creation of a serious risk to the health or safety of the public or section of the public. ${ }^{134}$ In the examples given by Dyson MR and the Independent Reviewer, these consequences have already occurred and the prosecution is concerned with proving whether the individual intended these consequences or was reckless as to whether they would come to fruition. However, the primary function of counterterrorist powers is to prevent the consequences in the first instance - to 'defend further up the field'. ${ }^{135}$ The preventative nature of counterterrorist powers is the driving force behind the breadth of the definition of terrorism. ${ }^{136}$ Interference with expression can therefore happen before publication or before the consequences occur. Journalists or other publishers are aware of this. Dyson MR's narrowing of

131 ibid [56]. 132 ibid [113].
135 D Anderson, 'Shielding the Compass' (2013) 3 EHRLR 233, 243.
136 C Walker, 'The Legal Definition of "Terrorism" in United Kingdom Law and Beyond' [2007] PL 331, 337. 
the definition is thus of minimal assistance to the journalist as the 'chilling effect' still remains.

The chilling effect could be avoided by a tighter definition of terrorism to apply when the 'action' that is seeking to be prevented is a form of written or verbal expression, rather than an act of violence. For example, amending 'influence the government' in section 1(1)(b) to 'designed to compel, coerce or intimidate' the government. ${ }^{137}$ This would increase the threshold of what would be considered a terrorist publication, thus mitigating the chilling effect by reassuring journalists that they have greater freedom to express themselves. The narrowing, however, would be limited only to specific offences, thus not hampering the operational necessity of a broader definition in circumstances where it is considered necessary.

By departing from the single definitional approach, clarity could be brought to this area by drafting a separate definition of terrorism deal with inchoate offences or offences that deal with the publication or dissemination of terrorism. In this way, the mental element could be more clearly refined and elucidated in a manner that Parliament may have been reluctant to do for all other offences or powers that derive from section 1. A multi-definitional approach could be used to design a legislative landscape for acts of terrorism committed outside the UK that would avoid, or at least reduce, the current reliance upon prosecutorial discretion that currently prevents its absurd, and at times hypocritical application.

\section{DEPARTING FROM THE SINGLE DEFINITION: LEGAL VERSUS POLITICAL FRAMES}

A multiple definitional approach to terrorism therefore has significant advantages for the rule of law and human rights. As stated previously, however, this approach has been criticized as amounting to an expression of inconsistency. ${ }^{138}$ Despite this concern, the UK's single definition of terrorism has also not been applied in a consistent fashion due to the broad discretion afforded to decision makers such as the CPS. Indeed, the UK government's actions overseas in Syria and Libya have also been inconsistent with this definition. Of course, section 1 was never designed to constrain the Government's actions; however, the argument may still be put that the inconsistency demonstrated by a multiple definitional approach may feed into public discourse on terrorism and thus reduce law's ability to influence this discussion. A key argument in favour of a single definition of terrorism that has not yet been confronted is the idea that by defining terrorism we can

\footnotetext{
137 The Independent Reviewer in his 2014 Report suggested changing 'influence' to 'designed to compel, coerce or undermine the government or an international organisation'. See D Anderson, 'The Terrorism Acts in 2013: Report of the Independent Reviewer on the Operation of the Terrorism Act 2000 and Part 1 of the Terrorism Act 2006' (TSO 2014) [10.35-10.43].

138 Perry (n 4).
} 
control it. ${ }^{139}$ This 'moral-political' condemnation of political violence can, according to this argument, shape the debate and control the use of who or what is labelled a terrorist. ${ }^{140}$ This argument thus conceptualizes law and legal definitions as shaping and framing the political debate; however, this contention overstates law's role in public discourse.

\section{A. Framing Public Discourse on Terrorism}

The subjective nature of the 'terrorist' label bestows a considerable power on the individual doing the categorizing. The British Government's use of the label 'terrorist' is not the application of the section 1 definition to a given individual or their acts; rather, we have seen that this conceptualization of terrorism deviates substantially from the legal definition, incorporating strategic political preferences and elements that are absent from section 1. It is this conception of terrorism - not the section 1 definition - that shapes and 'frames' the subsequent public discourse surrounding the nature of terrorism. ${ }^{141}$

According to RM Entman, to frame is 'to select some aspects of a perceived reality and make them more salient in a communicating text, in such a way as to promote a particular problem definition, causal interpretation, moral evaluation, and/or treatment recommendation for the item described'. ${ }^{142}$ Jim Kuypers further defines framing as:

... a process whereby communicators, consciously or unconsciously, act to construct a point of view that encourages the facts of a given situation to be interpreted by others in a particular manner. Frames operate in four key ways: they define problems, diagnose causes, make moral judgments, and suggest remedies. ${ }^{143}$

Frames thus affect the manner in which individuals perceive and understand events. In public discourse, there will be competing frames proffered from various sources. Meaning is not found but is created by rhetors and, in this regard, the executive above all other branches of government is best placed

139 Saul (n 42).

140 ibid.

141 Thus Conor Gearty argues that it is this actual use of this term 'terrorism' that shapes legal, political and public discussions on the issue. See C Gearty, 'Human Rights in an Age of CounterTerrorism' in C Gearty, Essays on Human Rights and Terrorism: Comparative Approaches to Civil Liberties in Asia, the EU and North America (Cameron May Publishers, 2008) 565-6; Grozdanova (n 44) 315.

142 RM Entman, 'Framing: Toward Clarification of a Fractured Paradigm' (1993) 43(1) Journal of Communication 51; Z Papacharissi and M de Fatima Oliveira, 'News Frames Terrorism: A Comparative Analysis of Frames Employed in Terrorism Coverage in US and UK Newspapers' (2008) 13(1) International Journal of Press/Politics 52, 53.

143 JA Kuypers, Bush's War: Media Bias and Justifications for War in a Terrorist Age (Rowman \& Littlefield 2009) 8; O Gross and F Ní Aoláin, 'The Rhetoric of War: Words, Conflict, and Categorisation Post-9/11' (2014) 24(2) Cornell Journal of Law and Public Policy 241, 247. 
to frame a crisis and interpret a particular act as terrorist or not. ${ }^{144}$ This is the case, regardless of whether there exists a settled definition of terrorism in law. In the aftermath of a so-called 'terrorist attack' the media will react by seeking to apply a previously used narrative in order to filter information and make sense of the unfolding events. ${ }^{145}$ Once the frame of 'terrorism' is established it dominates the reporting of the event to the exclusion of other competing frames. ${ }^{146}$ Familiar sources of information will be approached in order to expedite the explanation and this, in turn, facilitates the agendasetting role of the executive. ${ }^{147}$

\section{B. Constructing the Political Frame}

Framing theory thus explains how politicians and, in particular, the executive construct the public narrative surrounding terrorism; however, it does not explain why there is a marked disjuncture between the legal definition of terrorism and the image constructed by the political narrative. Defining what constitutes an enemy to the State is of fundamental importance to politics, and law enforcement and punishment has always been a key feature of sovereign power. ${ }^{148}$ The decision to differentiate friend from enemy is also closely linked to this expression of sovereignty. ${ }^{149}$ This distinction between legitimate and illegitimate political violence is not done through law but instead through a process of 'othering'. ${ }^{150}$

Stanley Cohen, in his seminal work on othering and moral panics termed the groups that are the subject of these panics 'folk devils'. ${ }^{151}$ The 'otherness' of these folk devils - such as the archetypal terrorist - are reinforced by crude stereo-types based on race, religion and other factors. This folk-devil construct of the archetypal terrorist may be strong enough to displace the actual reality of the terrorist threat facing a State, both in the minds of the public and political actors. Thus the threat from Islamic extremist terrorism is

\footnotetext{
144 Gross and Ní Aoláin, ibid; see also generally ME Stuckey, The President as Interpreter-inChief (CQ Press 1991); and RE Neustadt, Presidential Power: The Politics of Leadership from FDR to Carter (Wiley 1980).

145 P Norris, M Kern and M Just (eds), Framing Terrorism: The News Media, The Government, and the Public (Routledge 2003) 12-14.

146 See, for example, the June 2016 mass shooting in a gay nightclub in Orlando Florida. Initially framed as a homophobic attack, the subsequent establishment of a possible Islamic extremist motivation dominated the reporting of the event from that point on. See A Greene, 'Orlando Massacre shows our understanding of "terrorism" is too focused on jihad' The Conversation (14 June 2016) $<$ https://theconversation.com/orlando-massacre-shows-our-understanding-of-terrorismis-too-focused-on-jihad-60949>. 147 ibid.

148 See D Garland, 'The Limits of the Sovereign State' (1996) 36(4) British Journal of Criminology 445; P Kahn, 'Torture and Democratic Violence' (2009) 22(2) Ratio Juris 244.

149 See C Schmitt, The Concept of the Political (G Schwab trans, University of Chicago Press 2007) 26; E-W Bökenförde, 'The Concept of the Political: A Key to Understanding Carl Schmitt's Constitutional Theory' (1997) 10 Canadian Journal of Law and Jurisprudence 5;

150 D Garland, The Culture of Control: Crime and Social Order in Contemporary Societies (OUP 2001) 184 . ${ }^{151}$ See S Cohen, Folk Devils and Moral Panics (3rd edn, Routledge, 2002).
} 
more politically salient than that from dissident Irish republicanism, notwithstanding statistical evidence indicating that the latter has caused more deaths in the UK in the past five years than the former. ${ }^{152}$ Indeed, Islamic extremist terrorism is such a strong frame that when other forms of terrorism do occur, the media is often reluctant to frame the act as terrorism. Thus the killing of MP Jo Cox in June 2016 by Thomas Mair who allegedly shouted out 'put Britain first' and gave his name in court as 'death to traitors, freedom for Britain' clearly satisfied the definition of terrorism; however, there was an appreciable reluctance from many media outlets to frame it as such at the time. ${ }^{153}$ Instead, many outlets sought to emphasize Mair's struggles with mental illness; ${ }^{154}$ a factor which others convicted of offences related to Islamic extremist terrorism also faced. ${ }^{155}$ Moreover, the framing of Islamic terrorism as a global threat can be utilized to selectively conceptualize an attack anywhere in the world as an attack on the UK. A Government now does not have to experience first-hand an attack in its State for it to be able to invoke the rhetoric of an emergency, arguing that a threat exists which justifies exceptional counterterrorist measures that derogate from human rights and the rule of law. Islamic terrorism can thus be conceptualized as a global threat in a way that Irish republicanism never could.

The result of this is that the legal definition of terrorism cannot hope to control the use of the term 'terrorism' by political actors, the media or the public as a whole. Such arguments ignore the powerful functions that frames have in the public consciousness and agenda-setting, elevating the law to a lofty status of political influence that it simply does not occupy. At most, the legal definition of terrorism can only seek to demarcate and control public decision-makers when exercising counterterrorist powers. We have seen, however, that the current broad definition of terrorism contained in section 1 of the 2000 Act fails to do even that. This conclusion, while based on an analysis of British domestic law, also has ramifications for the necessity of a definition of terrorism in international law.

\footnotetext{
152 Anderson (n 3) 12.

153 D Boffey and N Slawson, 'Jo Cox accused gives name as "death to traitors, freedom for Britain"” The Guardian (18 June 2016) < https://www.theguardian.com/uk-news/2016/jun/18/jocox-murder-suspect-thomas-mair-told-police-he-was-political-activist>.

154 'Wrong to Make Political Capital from Jo Cox's Death' The Daily Express (17 June 2016) $<$ http://www.express.co.uk/comment/expresscomment/681026/jo-cox-mp-murdered-killed-wrongpolitical-capital $>$ P Foster, R Mendick and M Wilkinson, 'Thomas Mair: Man arrested in connection with Jo Cox attack was a "loner" with "history of mental health problems" The Telegraph (16 June 2016 ) <http://www.telegraph.co.uk/news/2016/06/16/jo-cox-mp-everything-we-know-so-far-aboutthomas-mair/>.

155 J Grierson, ' Leytonstone tube attacker "psychotic" at time of assault, court told" The Guardian (27 July 2016) <https://www.theguardian.com/uk-news/2016/jul/27/leytonstone-tubeattacker-muhiddin-mire-psychotic-court-told $>$ P Cheston and J Davenport, 'Lee Rigby murderer Adebowale "is borderline schizophrenic recommended for Broadmoor" The London Evening Standard (19 December 2013) <http://www.standard.co.uk/news/crime/lee-rigby-murdereradebowale-is-borderline-schizophrenic-recommended-for-broadmoor-9015617.html>.
} 


\section{CONCLUSIONS}

The UK's current definition of terrorism contained in section 1 of the TA 2000 has worrying implications for the principle of legality and human rights. Moreover, it has minimal impact in shaping public and political discourses regarding what constitutes terrorism. At most, the legal definition of terrorism can only seek to demarcate and control public decision-makers when exercising counterterrorist powers. We have seen, however, that the current broad definition of terrorism contained in section 1 of the 2000 Act fails to do even that. Instead, it paves the way for the socially constructed terrorist to influence decision makers.

Further counterterrorist or counter-extremist strategies may exacerbate this issue further. Recent policy pronouncements from the British Government indicating a shift towards tackling 'extremism' rather than 'terrorism' will potentially increase reliance by decision makers on this social construct. The aim of counterterrorist legislation is distinct from the ordinarily reactive criminal justice system and seeks to 'defend further up the field', preventing attacks from happening in the first instance. ${ }^{156}$ Focusing on 'extremism' rather than terrorism will shift this defence even further up. The British Government's 'Comprehensive Strategy to Defeat Extremism' Defines extremism as:

The vocal or active opposition to our fundamental values, including democracy, the rule of law, individual liberty and the mutual respect and tolerance of different faiths and beliefs. We also regard calls for the death of members of our armed forces as extremist. ${ }^{157}$

Whether this definition of such considerable breadth is transposed into law is unclear; nevertheless, any legal definition of extremism will invariably suffer from similar accusations of vagueness that plague the section 1 definition of terrorism. This in turn will result in a huge degree of decision-maker discretion being exercised in order to prevent abuses of counter-extremist powers, again undermining the principle of legality that is a fundamental cornerstone of the British Constitution.

The pragmatic solution that this article suggests is to abandon the single definition of terrorism and instead have multiple definitions the breadths of which vary according to the particular power exercised. An alternative solution is not a legal one but a political one. The UK could act in the conduct of its international affairs in a manner consistent with its domestic definition of terrorism. This would entail providing no material or financial support to groups that are using armed force against the government of specific States. This approach would also be consistent with international law which prohibits the support for rebel groups against the incumbent government.

156 Anderson (n 13).

157 Home Office, Counter Extremism Strategy (CM 9148, 2015) 9. 
This approach, however, in blunt terms, is unlikely to be realized. The power to distinguish friend from enemy is one that is intimately linked with sovereignty and one that governments will be loath to relinquish. ${ }^{158}$ Even with a clear legal definition of terrorism, governments will still deviate from this when it is advantageous. This tendency is amplified in the context of the quest for a single definition of terrorism in the international setting. If a domestic definition of terrorism, agreed upon and shaped by the government cannot control the government in its actions, there is little hope for the quest for an international definition of terrorism that seeks to control and bind the various disparate perspectives on terrorists and freedom fighters in international law. Indeed, it is for this reason that Conor Gearty argues that terrorism is far too useful a term for governments for it to be controlled. ${ }^{159}$ It is not the lack of a legal definition of terrorism in international law that has resulted in hegemonic powers like the US and UK deciding on a case-by-case basis who is the international public enemy. ${ }^{160}$

160 As suggested by Friedrichs (n 23) and Grozdanova (n 44). 